\title{
The study regarding the agrobiological and technological characteristics of some hybrid elites for table grapes obtained at N.R.D.I.B.H. Stefanesti
}

\author{
C. M. Ciobotea1*, D. Sumedrea1, A. Bădulescu1, R. Stan1, M. Bănuță1, M. Negru² \\ and A. Florea ${ }^{1}$ \\ ${ }^{1}$ National Research and Development Institute for Biotechnology in Horticulture, \\ Stefanesti, Romania \\ 2University of Pitesti, Faculty of Sciences, Physical Education and Informatics, \\ Department of Environmental Engineering and Applied Engineering Sciences, Pitesti, \\ Romania
}

*Corresponding author email: cioboteacristina76@yahoo.com

\section{ABSTRACT}

This paper aims to highlight the superior agrobiological and technological potential of hybrid genotypes, obtained by intraspecific hybridization of cultivars 'Victoria' x 'Black Pearl', 'Muscat de Poloskei' x 'Victoria', 'Coarnă neagră' x 'Victoria', 'Victoria' $x$ 'Victoria'. Several genotypes resulted from the hybridization of the mentioned cultivars, which stood out through at least two characters, similar or superior to the parental cultivar were selected in the comparative field. The evaluation of agro-biological characteristics of elites was based on the following indices: percentage of fertile shoots, fertility, and productivity coefficients. Technological descriptors related to the weight of the bunches, the weight of 100 berries, the skin's weight, the seeds, the content of the wort in sugars, the content of the wort in acidity were used in the study. The Victoria cultivar was taken as a witness, being considered a reference both nationally and internationally. The selected genotypes were distinguished by large grapes, very large grains, pleasant colors, high tolerance to biotic and abiotic factors. The new perspective elites show a high percentage of buds, high fertility, medium to high, the accumulation of sugars and total acidity in the must in a favorable way for mass consumption. To present more conclusively the multitude of data obtained, through statistical-mathematical processing, the general conclusions related to the mode of manifestation of hybrid elites in interaction with biotic and abiotic factors have been formulated considering the natural variability of all processes and phenomena involved.

Keywords: cultivar, hybridization, quality indicators, productivity indicators, parental forms

\section{INTRODUCTION}

In our country, the first cultivars of grape-vines with a known genetic origin, have been created since the sixth decade of the last century, and outstanding achievements obtained in improving cultivars were presented and published over the years, through many specialty papers, over the years (Constantinescu et al., 1959,1960, 1962,1965, 1966; Constantinescu, 1975; Constantinescu and Negreanu, 1960; Dvornic, 1960, 1974; Gorodea., 1976; Gorodea, 
1983; Negreanu and Lepădatu, 1971; Oprea and Gorodea, 1980; Oprea et al., 1983,1986; Lepădatu, 1979; Toma and Ispas, 2008).

Within the cultivated species $V$. vinifera, due to the complex genetic diversity, the intraspecific hybridization (free or directed), represented and remains the main method of creating variability, based on which most of the more valuable new cultivars existing in the current assortment were obtained. In this context, it is necessary to consider obtaining hybrids in which, due to gene recombination, the selection for quality, precocity, productivity, increased resistance to stress factors allow the identification of superior forms to the parents, from which later result in new cultivars. To achieve this objective, a judicious choice must be made of the parental forms which best express the desired characteristics. The conservation and evaluation of genetic resources (Vitis spp.) in germplasm banks have been the basis for their use in breeding programs, leading to the development of new cultivars (Coelho de Souza Leão et. al., 2011). In the field of table grape breeding, the most important objectives are: good fertility of cultivars, consistency of production from year to year or from one region to another; the balance between growth and fruiting; resistance or tolerance to diseases and pests, to reduce phytosanitary treatments; seedless; earliness and late ripening of grapes; the attractive appearance of the grapes (lax, large and uniform berries, the attractive color of the skin); the crunchiness and consistency of the pulp; pleasant aroma and taste; resistance to storage and transport (adhesion to the pedicel of the grains), (Grando Stella et. al., 2010). Hybrid populations obtained through the process of intra or interspecific hybridization, are characterized by genotypic and phenological heterogeneity, thus allowing the breeder to choose the most representative elites, which meet new combinations of hereditary factors. Leonte C. (1996) affirms that due to its complexity, productivity must be examined in terms of the productivity elements: number of fertile shoots per stump, number of bunches per stump, number of bunches per shoot, the weight of bunches, number of berries in the bunch, size of berries.

Sestraș R. (2004) opines that all these productivity elements have a polygenic type of heredity, being considerably influenced by both environmental and agrotechnical factors. Among the quality elements, the size of grapes and berries are characters that are important in terms of the commercial aspect of table grapes (Sestraş R., 2004).

\section{MATERIALS AND METHODS}

The research material consists of genotypes obtained from four hybrid crossing between cultivars 'Victoria' x 'Black Pearl' and 'Muscat de Polöskei' x 'Victoria', 'Coarnă neagră' x 'Victoria, Victoria' x Victoria'. These hybrid elites were coded as follows: 'BP 9', 'R10V', 'A5', and 'A6'. The option of intraspecific hybridization was chosen because most of the cultivars intended for fresh consumption are part of the species Vitis vinifera, the stages of simple hybridization were completed and the selection of hybrids in F1 was made. E1 X E2 $\rightarrow$ FI (E1 E2). F1 hybrids were obtained by manual castration of the maternal form and artificial pollination under the isolating sac.

The percentage of fertile shoots was determined from the total number of shoots per stump, the observations being made on all shoots on 10 stumps. The Victoria cultivar was taken as a control, is considered a reference for table grapes both nationally and internationally, with large fruits, pleasantly balanced taste, and increased resistance to biotic and abiotic factors. Also, in the category of agrobiological descriptors, the Fertility Coefficients (descriptors introduced by R.D.I.V.O. Valea Calugareasca) were calculated as follows: absolute (C.F.A.) representing the ratio between the number of bunches on the stem and the number of fertile shoots; relative (C.F.R.) - representing the ratio between the number of bunches on the stump and the total number of shoots. 
Productivity indices were also calculated. They are of two kinds: absolute and relative. Productivity indices (descriptors introduced by RDIVO Valea Calugareasca) are represented by: the absolute productivity index (I.P.A.), which expresses the product between the absolute fertility coefficient (C.F.A.) and the average weight of a grape and relative productivity index (I.P.R.), which expresses the product of the relative fertility coefficient (C.F.R.) and the average weight of a grape. Regarding the determinations made on the technological descriptors, they consisted in the repeated weighing of the grapes on 10 stems, over two years (2020-2021). The weight of the bunches, according to OIV codes 502, IBPGR 6.2.25.; ICVV 15.1., was determined at full maturity, by weighing the grapes from 10 shoots belonging to 10 different stems of the same genotype. The weight of the berry (OIV codes 503; IBPGR 6.2.26) was determined by weighing 100 berries, 10 berries from the median area of 10 grapes, from 10 different stems.

Also, in the category of technological descriptors, the content of the old wort was determined, with the help of the refractometer, making an average sample of all the grapes coming from 10 shoots from 10 stumps. The content of the must in acidity was determined by performing an average sample resulting from healthy and turgid berries from all grapes on 10 shoots. The glucoacidimetric index, which represents ratios between old (\%) / total acidity (g H2SO4/l) was also calculated. For the statistical interpretation of the results, the SPSS 14.0 program, which uses the Duncan test (multiple t-tests) for a 5\% statistical assurance was an aplyed.

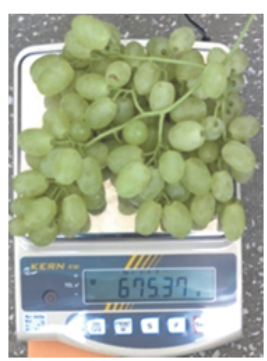

a

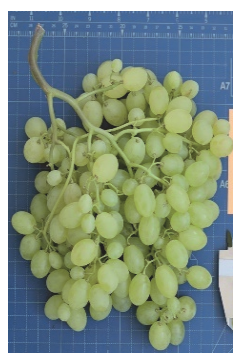

b

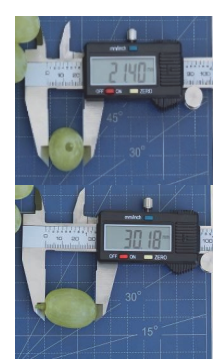

C

Figure 1. The appearance of grape elites

( $a, b, c$ - the weight of the grapes, the characteristics of the fruits)
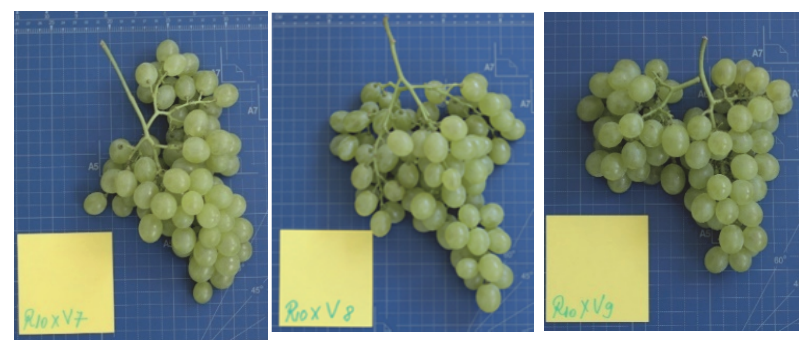

Figure 2. Appearance with the grapes of the 'R10/V' elite
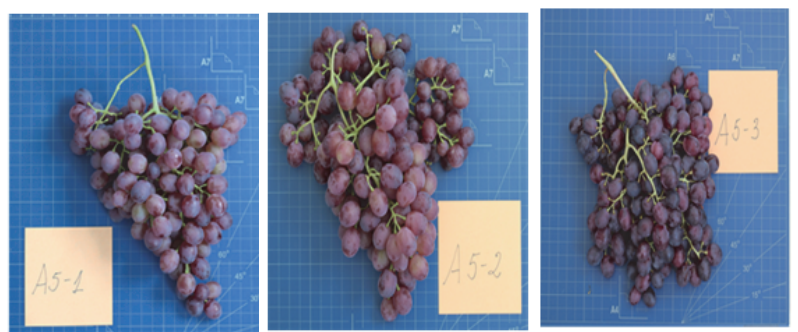

Figure 3. Appearance with the grapes of the 'A5' elite 


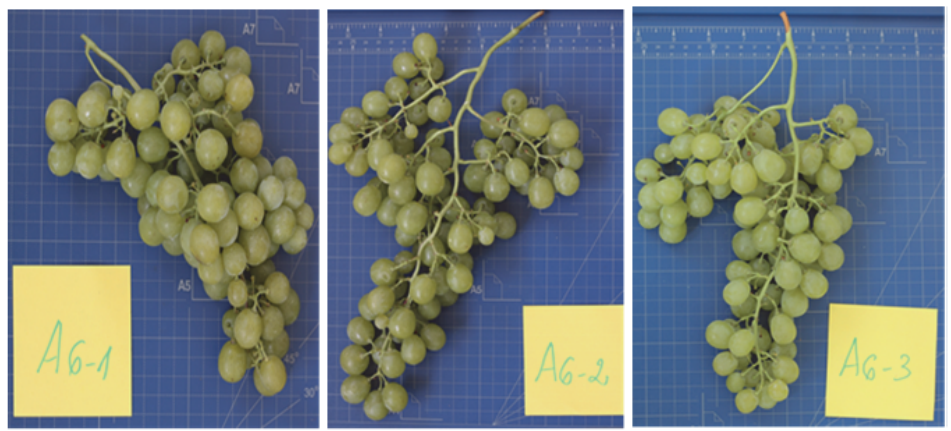

Figure 4. Appearance with the grapes of the 'A6' elite

\section{RESULTS AND DISCUSSIONS}

The geographical location of Stefanesti vineyard is between 44은 $42^{\prime}$ and $44^{\circ}$ 55' Nordic latitude at the southern edge of the platform Candesti in contact with the Romanian Plain. The vineyard is situated at altitudes between 200-415 m (maximum altitudes are Izvorani hill 415 meters and Pietroasa hill 325 meters).

The elites have been under study for over 10 years and are introduced for testing in the first year for approval. The data relating to the characteristics of fertility, productivity, and the quality of the hybrid elites represent averages of two years, 2019, 2020 respectively.

\section{Fertility and productivity characteristics}

Table 1. Viability and fertility of fruit buds

\begin{tabular}{|l|cc|c|cc|c|cc|c|}
\hline $\begin{array}{c}\text { Cultivar/ } \\
\text { Hybrid } \\
\text { Elite }\end{array}$ & $\begin{array}{c}\text { The total } \\
\text { number of shoot } \\
\text { per stump }\end{array}$ & $\begin{array}{c}\text { 5\% least } \\
\text { significant } \\
\text { difference }\end{array}$ & $\begin{array}{c}\text { The number of } \\
\text { fertile shoots }\end{array}$ & $\begin{array}{c}5 \% \text { least } \\
\text { significant } \\
\text { difference }\end{array}$ & $\begin{array}{c}\text { Number of } \\
\text { inflorescence }\end{array}$ & $\begin{array}{c}5 \% \text { least } \\
\text { significant } \\
\text { difference }\end{array}$ \\
\hline BP 9 & 20.00 & c & 1.000 & 20.00 & d & 1.000 & 4.00 & c & 0.163 \\
\hline A6 & 29.00 & b & 1.000 & 52.42 & a & 1.000 & 21.00 & bc & 0.360 \\
\hline A5 & 31.00 & a & 1.000 & 36.00 & b & 1.000 & 19.00 & bc & 0.360 \\
\hline R10/V & 32.00 & a & 0.073 & 36.82 & c & 1.000 & 16.00 & bc & 0.360 \\
\hline Victoria & 20.00 & c & 1.000 & 60.01 & c & 1.000 & 12.00 & c & 0.163 \\
\hline
\end{tabular}

Knowledge of bud fertility is an important aid in the selection of new cultivars of table grapes with high yield potential. In our study, the elites 'R10/V', 'A5', and 'A6' recorded the highest number of shoots $(32,32$, respectively 29$)$, surpassing the control that recorded only 20 shoots/stump, the differences between them being statistically assured. Elites 'A6', 'A5', and 'R10/V' had a good resistance to winter conditions - the percentage of fertile shoots varies from $52 \%$ ('A6') to $36.82 \%$ ('A5'), except for the elite 'BP'. Thus, the highest average fertility values were recorded in the control 'Victoria' (60\%), followed very closely by the elite 'A6' with fairly high fertility (52.42\%), the differences between them not being statistically assured. The weaker results of the number of inflorescences were highlighted in the' BP9' elite, although this group is characterized by an increased percentage of fertile shoots with 4 inflorescences (Table 1). The relative productivity index (Ipr) is an indicator, at least as important as the absolute productivity index (Ipa), which quantifies the production related to a crop area or a vineyard (Dumitriu, 2008), being an exponent of the particularity in interaction with environmental conditions (Oprea, 2001). The relative productivity index determines the production on a shoot and is implicitly related to the cultivation conditions. 
Table 2. Indexes of fertility and productivity for hybrid elites

\begin{tabular}{|c|c|c|c|c|c|c|c|c|c|c|c|}
\hline \multirow{2}{*}{$\begin{array}{l}\text { Cultivar/ } \\
\text { Hybrid } \\
\text { Elite }\end{array}$} & \multicolumn{7}{|c|}{ Fertility coefficients } & \multicolumn{4}{|c|}{ Productivity index } \\
\hline & $\begin{array}{r}\text { Rela } \\
\text { co } \\
((\end{array}$ & $\begin{array}{l}\text { ertility } \\
\text { ent } \\
\text { \%) }\end{array}$ & $\begin{array}{c}5 \% \text { least } \\
\text { significant } \\
\text { difference }\end{array}$ & $\begin{array}{c}\text { Absolute } \\
\text { fertility } \\
\text { coefficient }\end{array}$ & $\begin{array}{c}5 \% \text { least } \\
\text { significant } \\
\text { difference }\end{array}$ & $\begin{array}{c}\text { The } \\
\text { average } \\
\text { weight of a } \\
\text { grape }\end{array}$ & $\begin{array}{c}5 \% \text { least } \\
\text { significant } \\
\text { difference }\end{array}$ & $\begin{array}{c}\text { Relative } \\
\text { productiviti } \\
\text { index }\end{array}$ & $\begin{array}{c}5 \% \text { least } \\
\text { significant } \\
\text { difference }\end{array}$ & $\begin{array}{c}\text { Absolute } \\
\text { fertiliti } \\
\text { index }\end{array}$ & $\begin{array}{l}5 \% \text { least } \\
\text { significant } \\
\text { difference }\end{array}$ \\
\hline BP 9 & 0.19 & $\mathrm{e}$ & 1.000 & $1.00 \mathrm{~b}$ & 1.000 & $136.59 \mathrm{~d}$ & 1.000 & $25.95 \mathrm{e}$ & 1.000 & $136.59 \mathrm{e}$ & 1.000 \\
\hline A6 & 0.73 & $\mathrm{~b}$ & 1.000 & $1.37 \quad \mathrm{a}$ & 0.130 & $295.58 \mathrm{C}$ & 1.000 & $215.77 \mathrm{~d}$ & 1.000 & $404.94 \mathrm{~d}$ & 1.000 \\
\hline A5 & 0.61 & $\mathrm{C}$ & 1.000 & $1.35 \mathrm{a}$ & 0.130 & $375.95 \mathrm{~b}$ & 0.142 & 229.32 c & 1.000 & $507.51 \mathrm{c}$ & 1.000 \\
\hline R10/V & 0.50 & $d$ & 1.000 & $1.34 \mathrm{a}$ & 0.130 & $424.12 \mathrm{ab}$ & 0.288 & $235.50 \mathrm{ab}$ & 0.235 & $631.14 \mathrm{~b}$ & 1.000 \\
\hline Victoria & 0.80 & $a$ & 1.000 & $1.00 \mathrm{~b}$ & 1.000 & $471.80 \quad \mathrm{a}$ & 0.146 & $249.36 \quad$ a & 0.195 & $311.70 \mathrm{a}$ & 1.000 \\
\hline
\end{tabular}

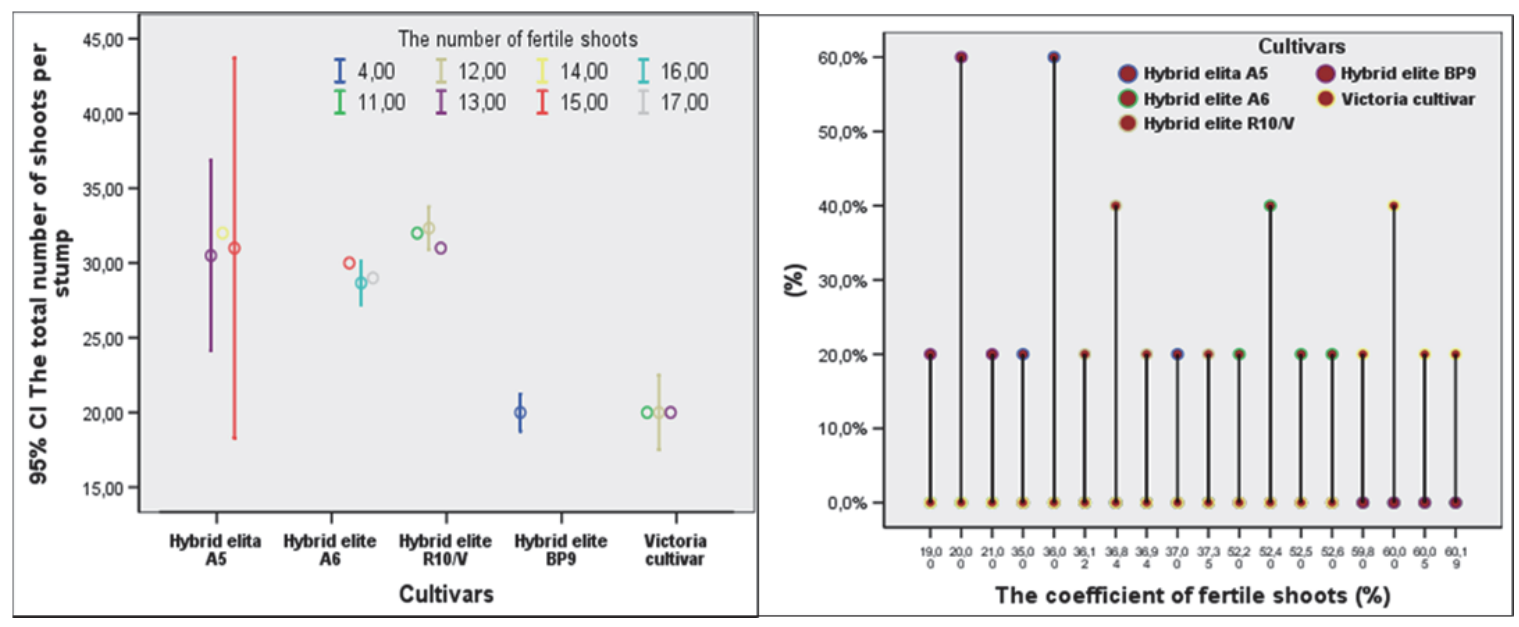

Figure 5. Percent of buds started in vegetation and percent of fertile shoots (mean value; I-95\% confidence interval).

\section{Technological characteristics of grape production.}

The study concerning the agrobiological characteristics referred to the average of grapes, a mass of 100 berries, number of berries/grape, the pulp of grape, the skin of a grape, and seed weight of grape complemented the knowledge elements for the hybrid elites studied.

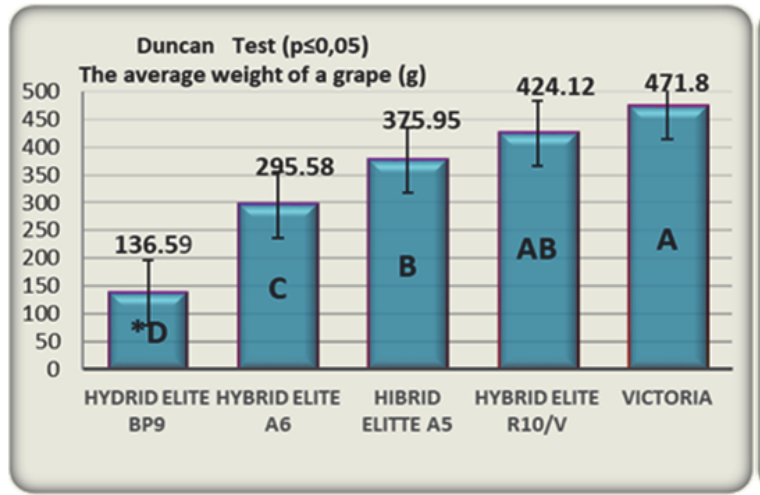

Figure 6. The average weight of a grape of the analyzed elite hybrids

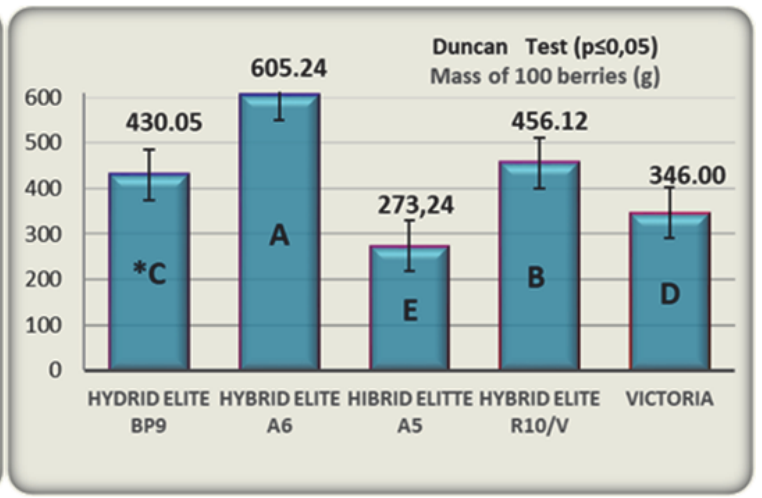

Figure 7. The mass of 100 berries of the analyzed elite hybrids

Regarding the average weight of a grape, it can be seen that the 'Victoria' cultivar recorded the highest average mass (471.8 g), followed very closely by the hybrid elite 'R1/V', the 
lowest being registered at the elite 'BP9', the differences between them being statistically insured, for an insurance level of 5\%, (Figure 6). These values correspond to the group of large grapes. Intermediate values were obtained for the hybrid elite 'A6' (295.58 g) and elite 'A5' with $375.95 \mathrm{~g}$. Berries size, expressed by weight of 100 grains on average presented values ranging from $605 \mathrm{~g}$ (Elite 'A6') and $273.24 \mathrm{~g}$ (elite 'A5'). Thus, the highest weight of 100 berries was recorded in the elite 'A6' (605.24 g/100 grapes), followed by the elites 'R10/V' and 'BP' elite, all this exceeding the control that recorded an average berries weight of only $346,0 \mathrm{~g}$, the differences between them being statistically insured, for an insurance level of $5 \%$ (Figure 7).

At the opposite pole, with an average weight of 100 grains below the analyzed control is situated the Elite 'A5'. Regarding the number of berries/grapes (g) statistically, significant differences between hybrid elites were obtained (Figure 7).

Therefore, the 'A6' hybrid elite (144 g) recorded the highest number of berries/grapes, followed by the analyzed control (126 g) and 'R10 / V' (99.4), the 'BP' and 'A5' elites (Figure 8). This is normal, a large number of berries/grapes, entails lower values of the weight of the grapes, which remain smaller.

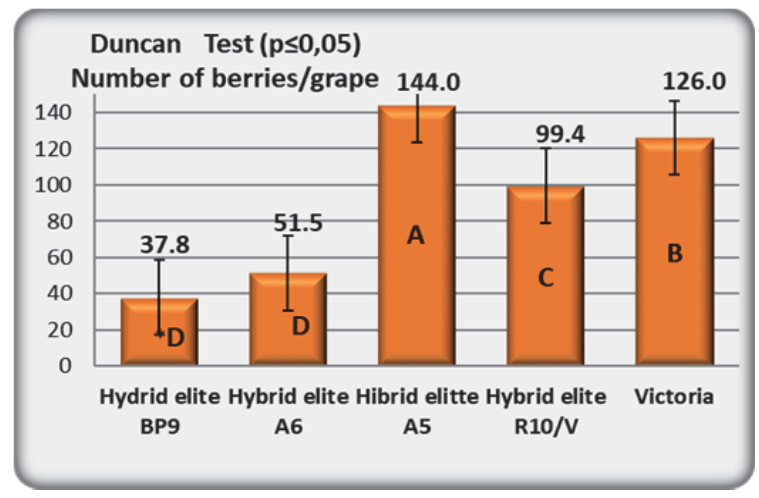

Figure 8. The number of berries/grapes

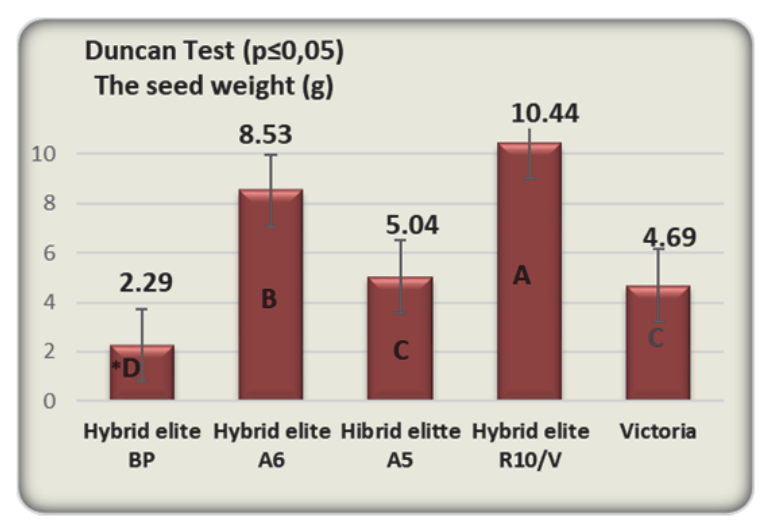

Figure 10. The average seed weight

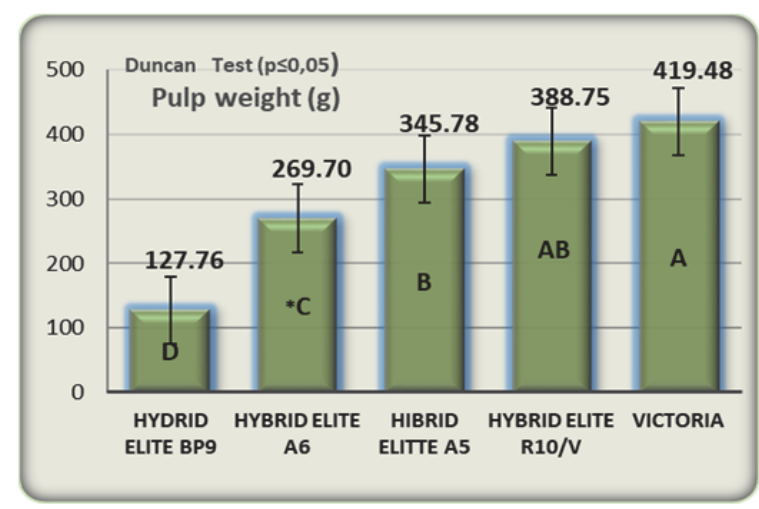

Figure 9. The average weight of the pulp

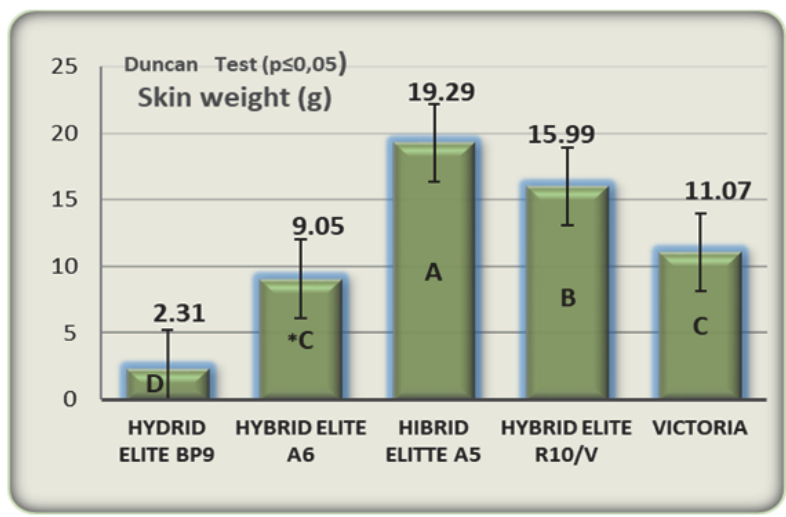

Figure 11. The average skin weight

Although statistically different, the results regarding the weight of the pulp show that the hybrid elites have high values and are close to the control. Thus, located on an intermediate homogeneity class, the elite 'R10/V' induced a high pulp weight (388.75 g) very close to the control (419.48 g), followed by the elites 'A5' (345.78 g) and 'A6' (269, 7g), (Figure 9). The lowest values of the pulp weight were highlighted in the case of the elite 'BP 9', (Figure 9). The weight of the seeds and the skin are quite important features in terms of describing the new cultivars of table grapes in viticulture. Although there were significant differences 
between the elites and the witness, it can be said that all the elites showed very good values of these indicators. Thus, the highest seeds weight was registered in the 'R10/V' hybrid elite (Figure10). With intermediate and close values, 'A5' and control were highlighted, these being included in the same intermediate class, according to the Duncan test. The lowest seed weight was highlighted in the BP hybrid elite (Figure 10).

\section{The qualitative characteristics of the perspective elites}

For determination of the quality of table grapes, priority is given to biochemical criteria, respectively to the content of must in sugar and acidity (Oprea, 2001). Sugars, along with acids are some of the most important elements of the quality of grapes.

The two biochemical components are particularly important in terms of the sugar/acidity ratio that decisively influences the taste of grapes (Sestraș, 2004; Bădulescu et al., 2020). From Figure 12 it can be seen that the elites recorded either a sugar content above the analyzed control ('A6') or values close to the control, although the differences between them are significantly different according to the Duncan test. The highest sugar content was highlighted in the 'A6' elite, followed by the control with $137 \mathrm{~g} / \mathrm{l}$ sugar and the lowest in the 'A5' elite (103.0 g/l), (Figure 12). Similar values, recorded on average over the 2 years of study were highlighted by Necula et. al., (2010), as a result of a study concerning the new table grape cultivars, in the Stefanesti area. The content of organic acids (total acidity \%) in fruits depends on several factors, including genotypic differences, pre-harvest climatic conditions, and post-harvest handling procedures (Popescu et. al., 2018). The titrable acidity of the must, expressed in g/l tartric acid, was determined at full maturity of the grapes. Although in the climatic conditions specific to the Stefanesti- Arges vineyard, the acidity of the must in the vine cultivars is generally maintained, the high temperatures of the last years influence this qualitative index (Ropan, 2009).

The average value of this parameter, during the 2019 - 2020 period ranged between $0.75 \mathrm{~g} / \mathrm{l}$ for the elite 'A6' and $0.36 \mathrm{~g} / \mathrm{l}$ for the 'A5' elite (Figure13).

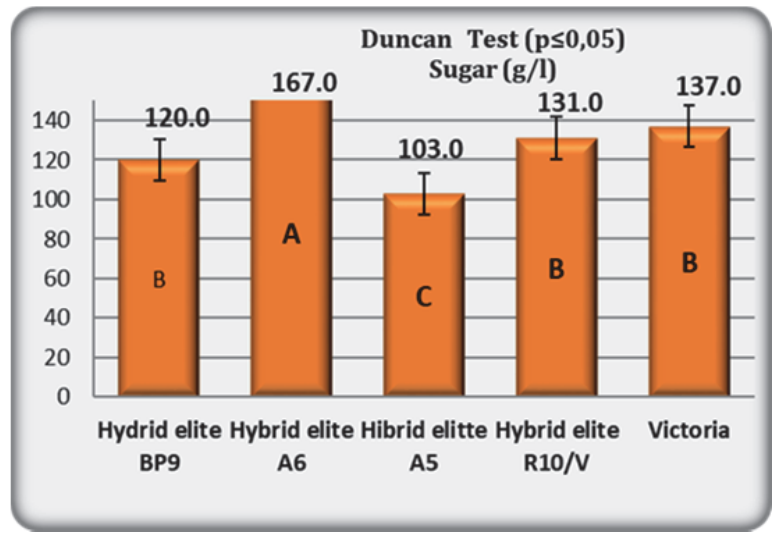

Figure 12. Sugar content at the elite hybrids

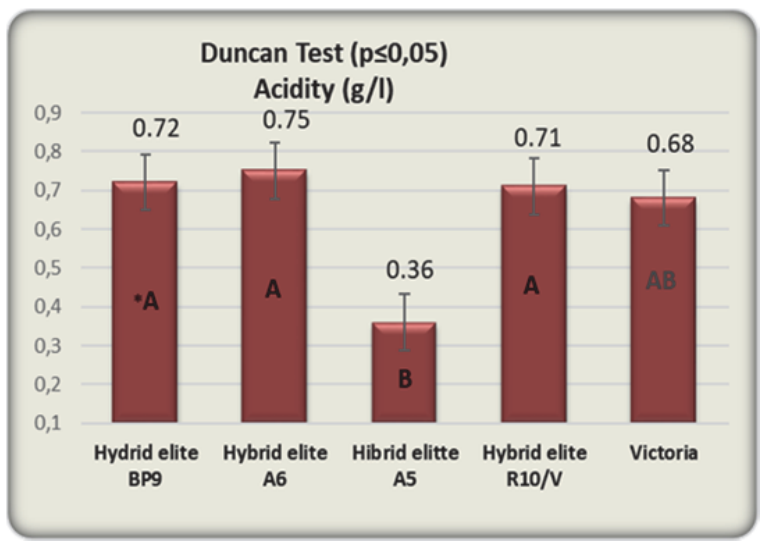

Figure 13. Total acidity at the elite hybrids

\section{CONCLUSIONS}

All elites taken into study have the potential to be used for the development of high-quality table grapes cultivars. As a result of the study, it was found that these elite cultivars, were distinguished by a good sugar/acidity balance and, in conclusion, can be proposed for approval. 
Separately or in various combinations of diversity the elites highlighted several important agrobiological features: high quality, including a relatively low number of seeds, productivity (a high average mass, which fit the elites in the category of large grapes), resistance to the stress factors given by the good results obtained on the fertility coefficient, other useful characteristics, presents a criterion for their inclusion in the germplasm prereproduction fund for later use in improving the assortment of the vineyard.

\section{REFERENCES}

1. Bădulescu A., Sumedrea D.I., Florea A., Onache A. and Tanase A. (2020). Influence of climate factors on yield and quality of some vine cultivars from the Stefănești Center. Romanian Journal of Horticulture. DOI 10.51258/RJH. (2020): 149-156.

2. Bucur G.M, and Dejeu L., (2018). Research On Phenotyping and Eno Carpologicaltraits of twenty-three new Romanian table grape cultivars (Vitis Vinifera L.). Agriculture for Life, Life for Agriculture, Bucharest. SCIEDO DOI: 10.2478/alife-2018-0040.

3. Constantinescu Gh. and Negreanu E., (1960) - Soiuri noi de viţă de struguri de masă cu coacere timpurie. Lucrări stiinţifice I.A.N.B, Seria B: 109-116.

4. Constantinescu Gh. (1959), (1960), (1962), (1965), (1966). Ampelografia R.S.R., Volumele II, III, IV, V, VI,VII, Editura Academiei București.

5. Constantinescu Gh., (1975). Problems of theoretical and applied genetics. Research institute for cereals and technical plants Fundulea. Plant Breeding Section, vol. VII, No. 4: 213-214.

6. Coelho de Souza L., Cruz C.D and Motoike S.Y, (2011). Genetic diversity of table grape based on 7. Dvornic V., (1960). A new perspective hybrid for table grapes. Scientific papers, I.A.N.B, Series B:139-143.

7. Dvornic V. (1974). Behavior of the elite for mass grapes 'Chasselas de Baneasa' in forest-steppe conditions. Annals of the I.C.D.V.V. Valea Călugărească, volume V: 61-68.

8. Dumitriu, I. C., (2008). Viticulture, Edit. Ceres, București

9. Gorodea Gr. (1976) - The study of vine cultivars for table grapes was recently introduced in the ampelographic collections. Annals of the I.C.D.V.V., vol. VII: 33-54

10. Gorodea Gr., (1983). Contributions to the study of hereditary variability of vine frost resistance. Annals of the I.C.D.V.V., vol. X: 55-64.

11. Grando Stella, Crespan Manna and Gasparo Marica (2010) . Miglioramento genetico. In: Angelini R. - L'Uva da Tavola. Ed. Script, Bologna.

12. Lepădatu V., (1979) - New cultivars for table grapes. Research in support of production - Viticulture and winemaking, Bucharest.

13. Leonte C., (1996)- Improvement of horticultural species - general problems, Ed. Didactică şi Pedagocică, Bucharest.

14. Necula Cezarina, Popa Camelia, Matei Viorica, Stefania Iordache and Stirbu Clara, (2010). Research on an agrobiological adaptation of table grapes cultivars in the vineyard Stefanesti-Arges. Annals. Food Science and Technology.

15. Negreanu E. and Lepădatu V., (1971) - Heredity of qualitative and quantitative traits and traits in F 1 vine hybrids. Annals of the I.C.D.V.V. Valea Călugărească, volume III: 21-36

16. Oprea Şt. and Gorodea Gr. (1980). New cultivars for table grapes. Research in support of viticulture and vinification production, Bucharest.

17. Oprea Şt. (1983). New vine cultivars for table grapes recently created in Romania. Analele I.C.D.V.V.Valea Călugărească, vol. X: 43- 54.

18. Oprea, ŞT. (2001). Viticulture, Edit. AcademicPres, Cluj Napoca

19. Popescu C.F., Bădulescu A., Ștefănescu D., and Călin G. (2018). The management of ex situ grapevine germplasm collections. Current Trends in Natural Sciences 7(13), pp: 252-260

20. Ropan., A. and Barbos I (2009). The influence of fruit position in the crown of trees on the sugar content and morphological traits of apple fruits, Bulletin of University of Agricultural Sciences and Veterinary.

21. Sestraș, R., 2004, Improvement of horticultural species. Ed. AcademicPres, Cluj-Napoca 